\title{
Distribution and Plasticity of Immunocytochemically Localized GABA Receptors in Adult Monkey Visual Cortex
}

\author{
S. H. C. Hendry, ${ }^{1}$ J. Fuchs, ${ }^{2}$ A. L. deBlas, ${ }^{3, a}$ and E. G. Jones ${ }^{1}$ \\ 'Department of Anatomy and Neurobiology, University of California, Irvine, California 92717, ${ }^{2}$ Department of Biological \\ Sciences, University of North Texas, Denton, Texas 76203, and ${ }^{3}$ Department of Neurobiology and Behavior, State \\ University of New York, Stony Brook, New York 11794
}

Immunocytochemical methods were used to reveal new details of the distribution and plasticity of $\mathrm{GABA}_{\mathrm{A}}$ receptors in the visual cortex of adult monkeys; the findings were compared with those of autoradiographic experiments involving the binding of ${ }^{3} \mathrm{H}$-muscimol and ${ }^{3} \mathrm{H}$-flunitrazepam. In both areas 17 and 18, a monoclonal antibody to the purified GABA $_{A}$ complex (deBlas et al., 1988) produced staining of punctate profiles in the neuropil and around cell bodies and large processes in layers I-VI. The receptor immunostaining was relatively intense in layers II-III, IVA, IVC $\beta$, and VI; these alternated with lightly stained layers I, IVB, IVC $\alpha$, and V. In area 18, the laminar pattern was similar except that layer IV was split into a superficial, lightly stained half and a deep, intensely stained half. In sections cut parallel to the pial surface, receptor distribution in most layers was found to be uniform. There were 3 exceptions in area 17: (1) patches of intense receptor staining were present in layers II and III; (2) a widely spaced, irregular lattice of intense staining was found in layer IVA; and (3) a much finer, regular lattice was present in layer IVC. The patches in layers II-III and the lattice in layer IVA coincided precisely with regions of intense cytochrome oxidase (CO) staining. The binding of ${ }^{3} \mathrm{H}$ muscimol and ${ }^{3} \mathrm{H}$-flunitrazepam revealed a laminar pattern that was similar in most respects, including greater ligand binding in layer IVA of area 17, but showed no evidence of the sublaminar organization in layers IVA and IVC $\beta$. Inhomogeneities in receptor immunostaining but not ligand binding were also seen in layer III of area 18.

Following a 5 or $\mathbf{1 0} \mathrm{d}$ period in which intravitreal injections of TTX had silenced ganglion cell activity in one retina, GA$B_{A}$ receptor immunostaining in layer IVC $\beta$ was distributed in intensely stained stripes, $450-550 \mu \mathrm{m}$ wide, that alternated with narrower, lightly stained stripes. Stripes were also seen with receptor immunostaining and with the binding of the 2 radioligands in layer IVC $\beta$ of monocularly enucleated monkeys. Comparison with $\mathrm{CO}$ staining revealed that the stripes of reduced immunostaining or ligand binding corresponded

\footnotetext{
Received Sept. 21, 1989; revised Feb. 8, 1990; accepted Feb. 27, 1990.

We thank Christopher Ngyuen and Brian Miyazaki for technical assistance. Supported by grants EY 06432 and EY 07193 from the National Institutes of Health, United States Public Health Service.

Correspondence should be addressed to S. H. C. Hendry at the above address.

a Present address: Division of Molecular Biology, University of Missouri, Kansas City, Kansas City, MO 64110.

Copyright (C) 1990 Society for Neuroscience $0270-6474 / 90 / 072438-13 \$ 03.00 / 0$
}

to columns dominated by the TTX-injected or enucleated eye. Quantitatively, the binding in the deprived eye columns was reduced by $25 \%$. These findings indicate that the distribution of GABA $_{A}$ receptors in monkey area 17 closely matches the previously reported distribution of cells and axon terminals immunoreactive for GABA and suggest that $\mathrm{GABA}_{\mathrm{A}}$ receptors in adult monkeys undergo a rapid, activitydependent change in density or structure with monocular deprivation.

One out of 5 neurons in area 17 of the cerebral cortex of normal adult monkeys is GABA immunoreactive (Fitzpatrick et al., 1987; Hendry et al., 1987). Although present in all layers of area 17 , the cell bodies and terminals of these neurons are most densely concentrated in layers receiving direct connections from the dorsal lateral geniculate nuclei (Hendrickson et al., 1981; Fitzpatrick et al., 1987; Hendry et al., 1987). Thus, the GABA neurons are in a position to influence the first stages of visual processing within the cerebral cortex. A combination of physiological and pharmacological approaches indicates that this influence is inhibitory when mediated by the bicuculline-sensitive $\mathrm{GABA}_{\mathrm{A}}$ receptor (Krnjević, 1984; Sillito, 1984).

The $\mathrm{GABA}_{\mathrm{A}}$ receptor is a complex that is coupled to a chloride channel and includes binding sites for benzodiazepines and barbiturates (Olsen, 1981, 1982; Bowery et al., 1984; Tallman and Gallagher, 1985; Kuriyama and Taguchi, 1987). Because the receptor is involved with inhibitory synaptic transmission throughout the CNS (Bowery, 1983; Johnston et al., 1984; Roberts, 1986), its distribution in the mammalian brain has been closely examined (Young and Kuhar, 1979, 1980; Richards et al., 1984, 1987; deBlas, 1988; Houser et al., 1988). In area 17 of monkeys, the distribution of autoradiographically localized $\mathrm{GABA}_{\mathrm{A}}$ receptors in many respects matches the distribution of GABA neurons (Shaw and Cynader, 1986; Rakic et al., 1988). However, with the limited resolution of the ligand binding method, $\mathrm{GABA}_{\mathrm{A}}$ receptor distribution has not been fully determined for sublaminar regions with elevated GABA terminal density, including the patches of cytochrome oxidase $(\mathrm{CO})$ staining in layers II and III and the honeycomb of CO staining in layer IVA (Hendrickson et al., 1981; Fitzpatrick et al., 1987).

In the present study we have used a monoclonal antibody to localize immunocytochemically $\mathrm{GABA}_{\mathrm{A}}$ receptors in areas 17 and 18 of macaque monkeys and have compared the results with patterns produced by the binding of the GABA agonist, ${ }^{3} \mathrm{H}$-muscimol, and the benzodiazepine, ${ }^{3} \mathrm{H}$-flunitrazepam. Pre- 
vious studies using this approach in other species and in other parts of the brain have found similar distributions of immunocytochemically and autoradiographically localized receptors (Schoch et al., 1985; Richards et al., 1987; Houser et al., 1988), but have reported a more detailed pattern with immunocytochemistry. We have examined the distribution of $\mathrm{GABA}_{\mathrm{A}}$ receptors in normal monkeys and in monkeys deprived of input from one retina, either by the intravitreal injection of the sodium channel blocker, TTX, or the surgical removal of one eye. These latter experiments were prompted by studies which showed that the immunostaining for GABA and for its synthesizing enzyme, glutamate decarboxylase (GAD), were reduced within area 17 neurons deprived of their normal visual input (Hendry and Jones, 1986, 1988). By examining $\mathrm{GABA}_{\mathrm{A}}$ receptors in monocularly deprived monkeys, we found that, as with GABA itself, the receptors appear to undergo an activity-dependent change in number or structure within deprived-eye columns.

\section{Materials and Methods}

Ten adult monkeys (Macaca fascicularis or Macaca mulatta) weighing $2.5-7.5 \mathrm{~kg}$ were used in this study. Six monkeys were used for immunocytochemistry: 3 were normal, 2 had TTX $(15 \mu \mathrm{g} / 10 \mu \mathrm{l})$ injected under Ketamine anesthesia into the vitreous cavity of 1 eye $5 \mathrm{~d}$ (single injection) or $10 \mathrm{~d}$ previously ( 2 injections, $5 \mathrm{~d}$ apart) and 1 had 1 eye removed under barbiturate anesthesia 1 week prior to death. All these monkeys were given overdoses of Nembutal and were perfused through the heart with $4 \%$ paraformaldehyde and $0.02-0.05 \%$ glutaraldehyde in $0.1 \mathrm{M}$ phosphate buffer. Four other monkeys were used for receptor autoradiography: 2 were normal and 2 had 1 eye removed under barbiturate anesthesia 1 or 2 weeks previously. All were killed by an overdose of Nembutal but were not perfused. The brains were quickly removed, cut into blocks, and frozen in isopentane at $-70^{\circ} \mathrm{C}$.

Most blocks of aldehyde-fixed occipital lobes were infiltrated with $20 \%$ sucrose in phosphate buffer and were frozen on dry ice. Selected blocks of the occipital operculum were flattened before they were frozen. Serial sections, alternating at 20 and $40 \mu \mathrm{m}$, were cut on a sliding microtome. Other blocks were cut at 20 and $40 \mu \mathrm{m}$ on a Vibratome. The thicker sections were stained for CO activity (Wong-Riley, 1979). The thinner sections were pre-incubated in $3 \%$ normal horse serum and $0.1 \%$ Triton X-100 in 0.1 m phosphate buffer (dilution buffer). They were transferred to a solution containing a monoclonal antibody to the $\mathrm{GABA}_{\mathrm{A}}$ receptor (deBlas et al., 1988; Vitorica et al., 1988), diluted 1:250 in dilution buffer, and incubated for $48-72 \mathrm{hr}$ at $4^{\circ} \mathrm{C}$. They were subsequently processed by the avidin-biotin-peroxidase method (Hsu et al., 1981; Vector Labs) and reacted in 3,3'-diaminobenzidine tetrahydrochloride and hydrogen peroxide. Some immunostained sections were counterstained with thionin. Control sections were incubated in normal mouse serum or supernatant from a nonsecreting cell line instead of specific antireceptor antibody. The frozen sections were mounted on gelatin-subbed slides, dehydrated, and coverslipped. The Vibratomecut sections were postfixed in $1 \%$ osmium tetroxide for $5 \mathrm{~min}$, dehydrated in ethanol, and embedded in Spurr's resin. Pieces of these sections were then resectioned at $1 \mu \mathrm{m}$ on a Reichert Ultracut ultramicrotome and heat-mounted onto clean slides.

Blocks of fresh-frozen tissue were cut at $20 \mu \mathrm{m}$ on a cryostat. Sections were stored at $-70^{\circ} \mathrm{C}$ until they were processed for binding of ${ }^{3} \mathrm{H}$ muscimol (Mower et al., 1986) or ${ }^{3} \mathrm{H}$-flunitrazepam (Unnerstall et al., 1982). For muscimol binding, sections were preincubated in $0.3 \mathrm{M}$ Triscitrate buffer $\left(\mathrm{pH} \mathrm{7.1)}\right.$ for $30 \mathrm{~min}$ at $4^{\circ} \mathrm{C}$, then incubated in $10 \mathrm{nM}^{3} \mathrm{H}$ methyl-muscimol (New England Nuclear, $20 \mathrm{Ci} / \mathrm{mmol}$ ) in Tris-citrate buffer. For flunitrazepam binding, sections were preincubated in 0.17 м Tris- $\mathrm{HCl}$ buffer ( $\mathrm{pH} \mathrm{7.4)}$ for $10 \mathrm{~min}$ at room temperature, then incubated for $40 \mathrm{~min}$ at $4^{\circ} \mathrm{C}$ in $1 \mathrm{nM}^{3} \mathrm{H}$-methyl-flunitrazepam (Amersham, $90 \mathrm{Ci} / \mathrm{mmol}$ ). All scctions wcrc bricfly rinsed (3 10-sec rinses in buffer) at $4^{\circ} \mathrm{C}$, dried, and exposed to LKB Ultrofilm together with tritium standards (Amersham). In control experiments for muscimol binding, sections were incubated under the same conditions as above but with the addition of $1 \mu \mathrm{M}$ unlabeled GABA. Flunitrazepam control sections were processed with $1 \mu \mathrm{M}$ clonazepam added to the incubation medium. Sections were exposed for 1 or 5 months. The film was then developed and the sections were stained for $\mathrm{CO}$. The autoradiograms were analyzed and compared with the $\mathrm{CO}$ staining patterns by using an MCID image analysis system, which allowed the superimposition of the autoradiograms and the histochemically stained sections in order to measure binding in precisely defined layers, sublaminar compartments, and ocular dominance columns.

\section{Results}

\section{Cellular localization}

$\mathrm{GABA}_{\mathrm{A}}$ receptor immunoreactivity was present through the thickness of area 17 and in the subjacent white matter. Staining of the neuropil was evident in all 6 layers and consisted of rich plexuses of punctate profiles (Fig. $1 A$ ). The punctate nature of the staining was particularly evident in the semithin sections. Most of the immunostained profiles were small circular elements, approximately $1-2 \mu \mathrm{m}$ in diameter, but some were larger and irregularly shaped. Embedded in the neuropil, conspicuous by their lack of staining, were the somata of pyramidal and nonpyramidal neurons (Fig. $1 A$ ). The size of the puncta and the intensity of their staining were often greater around the somata and proximal dendrites, so that parts of neurons were outlined by the localization of the receptors. This was particularly striking in area 18, where intense receptor staining frequently surrounded bundles of radially oriented processes (Fig. $1 B$ ).

In the deepest part of layer VI and more frequently in the underlying white matter, the density of neuropil receptors was sufficiently low that the outlines of single cells, including portions of their dendritic trees, could be traced by the surrounding punctate immunostaining (Fig. 1C). The cells outlined in this manner were invariably nonpyramidal cells with radiating dendrites, similar in morphology to the neuropeptide-immunoreactive neurons previously localized in the white matter subjacent to areas 17 and 18 (Hendry et al., 1984; Kuljis and Rakic, 1989).

Immunostaining in the control experiments was light and very diffuse.

\section{Laminar distribution}

Area 17 immunostaining. The intensity of receptor immunostaining varied across layers in area 17; the resulting pattern of immunostaining (Figs. $2 A, 3 B$ ) was compared with the pattern of $\mathrm{CO}$ staining in adjacent sections (Figs. $2 B, 3 \mathrm{C}$ ) and with the pattern of GABA immunostaining (Fig. 2C). As judged from relative levels of immunoreactivity, receptor density in layer I was moderate while that in layers II and III was high. However, the intensity of receptor immunostaining was greater in layer II and declined progressively through the thickness of layer III. Layer IV was split into 4 bands of staining: receptor immunostaining was very intense in layer IVA, very light in layer IVB, light-to-moderate in layer IVC $\alpha$, and very intense in layer IVC $\beta$. Underlying layer IVC $\beta$ was a lightly immunostained layer $\mathrm{V}$, and a relatively intensely stained layer VI (Fig. $3 B$ ). Near the border with the underlying white matter, the density of rcceptors dcclined markedly, yet for approximately $1 \mathrm{~mm}$ deep to the cortex, punctate receptor staining was still apparent either around individual cell bodies and dendrites or scattered diffusely.

Area 18 immunostaining. The intensity of $\mathrm{GABA}_{\mathrm{A}}$ receptor immunoreactivity also varied in area 18 (Fig. 3). Relatively intense staining was found in a superficial band, which included layers I, II, and superficial III. The remainder of layer III and the superficial half of layer IV were lightly stained. Intense im- 

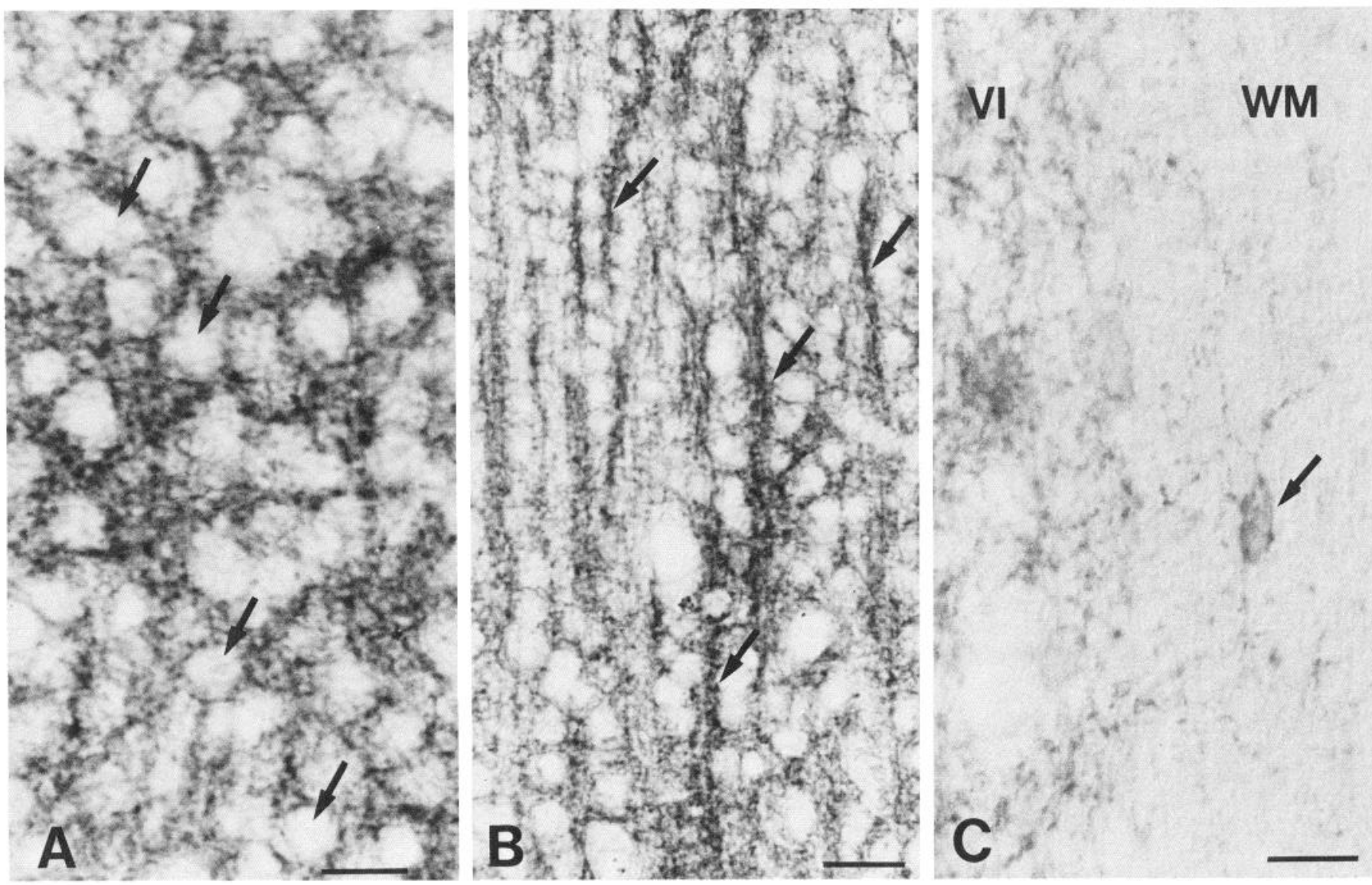

Figure 1. High magnification photomicrographs of $\mathrm{GABA}_{\mathrm{A}}$ receptor immunostaining in areas 17 and 18. A, Immunostained punctate profiles, which are likely to be aggregates of receptors, surround circular unstained regions (arrows) in layers II and III of area 17. The unstained regions were identified as neuronal cell bodies in counterstained sections. B. Immunostained puncta in layer III of area 18 . The puncta surround radially oriented processes in this layer and in the superficial half of the layer IV. $C$, Immunostaining deep in layer VI and in the subjacent white matter $(W M)$ of area 17. The density of stained puncta at this depth is relatively low, so that the outlines of individual somata (arrow) and their processes are apparent. Scale bars, $15 \mu \mathrm{m}$ in $A$ and $C, 20 \mu \mathrm{m}$ in $B$.

munostaining was found in the deep half of layer IV and moderate staining was found in layer VI. Between them was the lightly stained layer V. Thus, the receptor patterns in areas 17 and 18 differed principally in layer IV (Fig. $3 B$ ). This difference was sufficient for the border between the 2 areas to be clearly marked (Fig. 3, B, C).

Radioligand binding. The laminar distribution of radiolabeled $\mathrm{GABA}_{\mathrm{A}}$ receptors in area 17 was similar to the distribution of immunostained receptors. Variations in the density of ${ }^{3} \mathrm{H}$-muscimol and ${ }^{3} \mathrm{H}$-flunitrazepam binding were apparent across layers $\mathrm{I}-\mathrm{VI}$ and included a band of increased ${ }^{3} \mathrm{H}$-muscimol binding in layer IVA (see Fig. 9A). In area 18 the pattern of ${ }^{3} \mathrm{H}$-flunitrazepam binding closely resembled the distribution of immunostained receptors. The ${ }^{3} \mathrm{H}$-muscimol binding was denser in layers II and III than in other layers (see Fig. $9 D$ ).

\section{Intralaminar patterns of receptor density}

The immunostaining for $\mathrm{GABA}_{\mathrm{A}}$ receptors formed distinct patterns within 3 regions of area 17 and in 1 layer of area 18 .

Layer II-III patches. In layers II and III of area 17, periodic high intensities of receptor immunoreactivity occupied patches that measured $150 \times 250 \mu \mathrm{m}$ (Fig. 4). In sections cut parallel to the pial surface, the patches lined up in rows with a centerto-center spacing of 350-550 $\mu \mathrm{m}$ (Fig. $4 A$ ). Comparison with adjacent sections histochemically stained for CO (Fig. $4 B$ ) revealed that the receptor patches coincided with the periodic patches of high $\mathrm{CO}$ staining, which have also been called puffs (Carroll and Wong-Riley, 1984), blobs (Livingstone and Hubel, 1984a, b), or dots (Hendrickson et al., 1981). Approximately $3 / 4$ of the CO-stained patches coincided with patches intensely immunoreactive for $\mathrm{GABA}_{\mathrm{A}}$ receptors. Those $\mathrm{CO}$ patches that coincided with regions of light receptor immunostaining formed no obvious pattern.

Many immunoreactive punctate profiles within regions corresponding to the $\mathrm{CO}$ patches appeared to be larger and more intensely stained than the profiles of the surrounding interpatch regions. However, even with the improved resolution of semithin sections, it could not be determined whether an increase in the overall density of punctate profiles also contributed to the increase in immunostaining.

Layer IVA honeycomb. In layer IVA of area 17 , intense $\mathrm{GABA}_{\mathrm{A}}$ receptor immunostaining formed a conspicuous honeycomb pattern (Fig. 5). This pattern consisted of cores with a low density of puncta surrounded by walls with a high density. The cores were of irregular shape and size, with the largest approaching $300 \mu \mathrm{m}$ in diameter. They contained unstained somata invested by small immunoreactive puncta(Fig. 5C). Around the cores were walls that varied in thickness from 10 to $40 \mu \mathrm{m}$. 

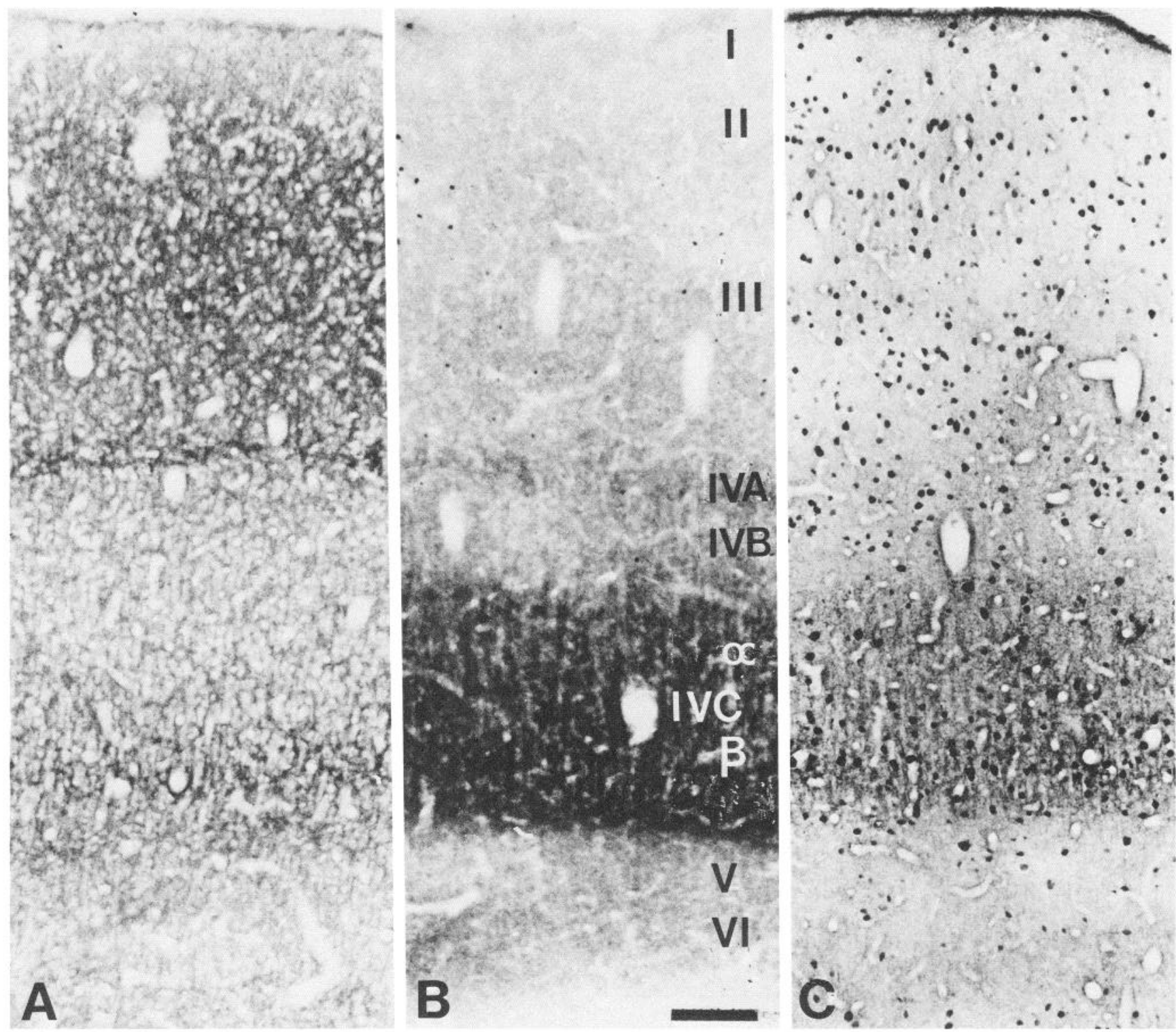

Figure 2. Laminar distribution of $\mathrm{GABA}_{\mathrm{A}}$ receptor immunostaining $(A)$ and GABA immunoreactive neurons $(C)$ in area 17 . $A$, Receptor immunostaining is densest in 3 bands which, by comparison with an adjacent section stained for CO (B), can be identified as layers II-III, IVA, and IVC $\beta$. $C$, Immunostaining with an anti-GABA antiserum reveals high densities of GABA somata and terminals in these same layers. Scale bar, $100 \mu \mathrm{m}$.

By focusing through this intensely stained lattice, it was apparent that each wall consisted of many long strands of puncta stacked one on top of another (Fig. $5 C$ ). Often a single wall was split in 2 by the presence of 1 or more unstained somata and occasionally a few strands of puncta would subdivide a lightly stained core.

The irregular pattern of $\mathrm{GABA}_{\mathrm{A}}$ receptor distribution in layer IVA was compared with a very similar pattern found with $\mathrm{CO}$ staining (Fig. 5, $A, B$ ). Analysis of adjacent sections showed that the receptor pattern and the $\mathrm{CO}$ pattern were similar: both formed honeycomb patterns and the walls of intense receptor immunostaining coincided with the walls of intense $\mathrm{CO}$ staining. However, the light microscopic appearance of the $\mathrm{CO}$ staining was much less punctate.

Layer IVC lattice. GABA $\mathrm{A}_{\mathrm{A}}$ receptors were also densely packed within a very fine lattice in layer IVC $\beta$ of area 17 (Fig. 6). Rarely were long strands of immunostained puncta present and these did not form an obvious pattern. Instead a meshwork of very short, thin strands and individual puncta invested themselves around numerous small, unstained regions made up of cell bodies and radially oriented processes (Fig. $6 \mathrm{~A}$ ). A similar, though less distinct lattice was seen in adjacent CO-stained sections (Fig. 6B). The fine lattice of receptor immunostaining and of $\mathrm{CO}$ staining did not vary in pattern or intensity in tangential sections through layer IVC $\beta$ of the normal monkeys and so the impression at low magnification was of a uniformly stained layer (Fig. 6, $C, D$ ).

Although the immunostaining of layer IVC $\alpha$ was less intense than that of layer IVC $\beta$, the $\mathrm{GABA}_{\mathrm{A}}$ receptor immunostaining was nonetheless densest within the walls of a fine lattice, which gave the impression of a homogeneous pattern at low magnification. 


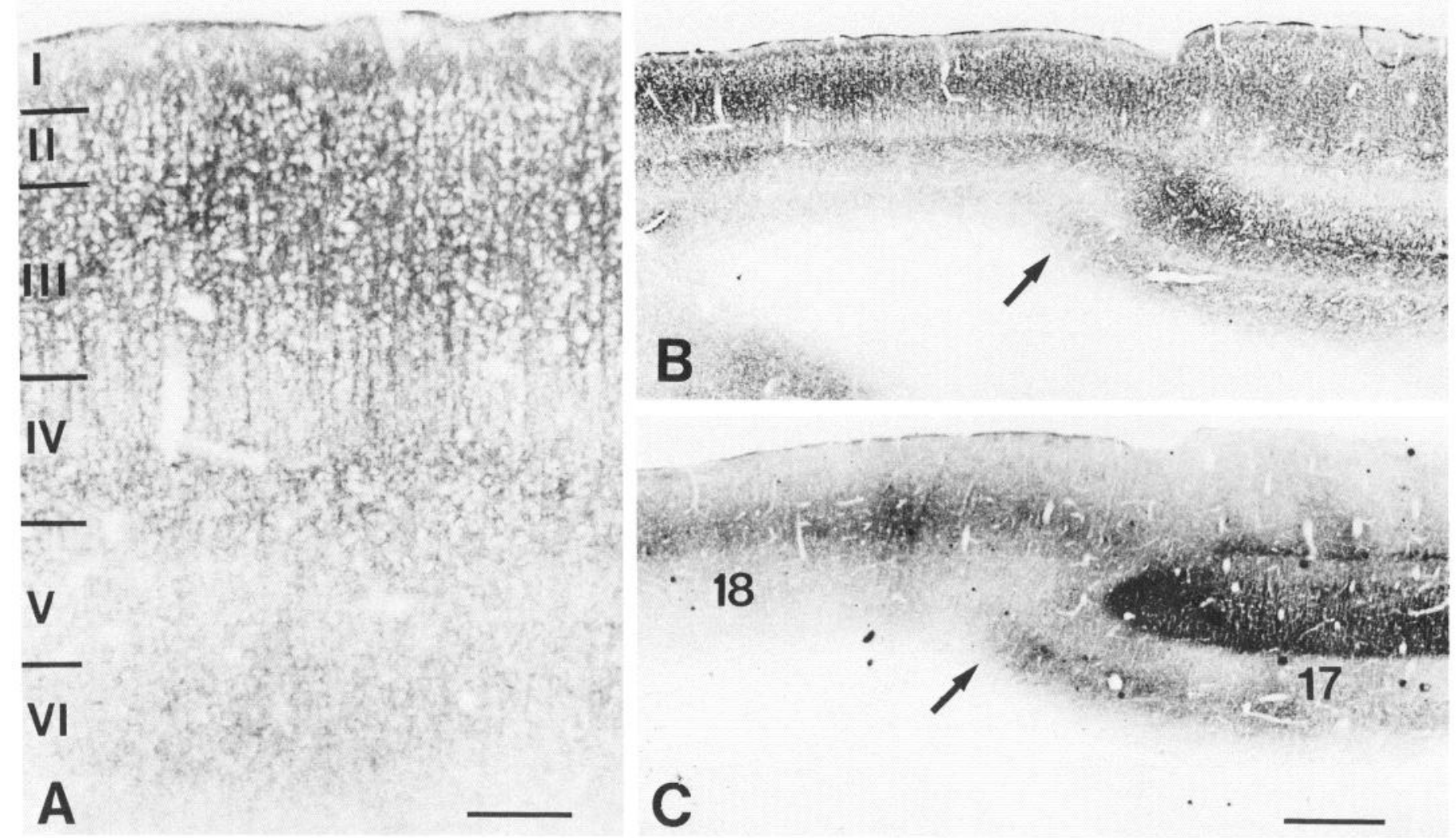

Figure 3. Photomicrographs of sagittal sections through the monkey occipital lobe. $A, \mathrm{GABA}_{\mathrm{A}}$ receptor immunostaining in area 18 is intense in layer II and the superficial half of layer III, is lighter in the deep half of layer III and the superficial half of layer IV, intense in the deep half of layer IV, light in layer V, and moderate in layer VI. Layers were determined by comparing the immunostained sections with adjacent thioninstained and CO-stained sections. $B$ and $C$, The differences in intensity and laminar pattern of receptor immunostaining $(B)$ and $C O$ staining $(C)$ in adjacent sections through areas 17 and 18 clearly delineate the border (arrows) between the two areas. Both receptor immunostaining and CO staining are inhomogeneous in area 18 but the 2 patterns apparently do not correspond. Scale bars, $250 \mu \mathrm{m}$ in $A, 400 \mu \mathrm{m}$ in $B$ and $C$.

Area 18. In area 18, the generally light immunostaining in the deep half of layer III and the superficial half of layer IV was interrupted by very thin strands of intensely stained puncta. These were radially oriented and were invariably found on either side of wider (10-15 $\mu \mathrm{m})$ unstained regions. Thus, the appearance in layer III was of $\mathrm{GABA}_{\mathrm{A}}$ receptors surrounding bundles of apical dendrites and possibly other radially oriented processes (Figs. $1 B, 3 A$ ).

The distribution of $\mathrm{GABA}_{\mathrm{A}}$ receptor immunostaining was not uniform in area 18 , as regions of relatively intense staining in layers II-III and IV alternated with regions of lighter staining (Fig. 3B). However, there appeared to be no correlation between the periodic intense immunostaining and the well-known bands of $\mathrm{CO}$ staining in this area (Fig. $3 C$ ).

\section{Plasticity of $G A B A_{A}$ receptors in area 17}

In sections cut either perpendicular or parallel to the pial surface of the occipital lobe of normal monkeys, no periodicities in receptor immunostaining or $\mathrm{CO}$ staining were evident in layer IVC $\beta$ (Fig. 6, $C, D$ ). By contrast, in tangential sections cut from area 17 of TTX-injected or enucleated monkeys, the distribution of $\mathrm{GABA}_{\mathrm{A}}$ receptors in layer IVC $\beta$ was distinctly periodic (Fig. 7). In these monkeys, $450-650 \mu \mathrm{m}$-wide stripes of intense immunostaining alternated with lightly stained, narrower stripes (Fig. 7A). In autoradiograms from enucleated monkeys, stripes displaying the normal high levels of ${ }^{3} \mathrm{H}$-muscimol or ${ }^{3} \mathrm{H}$-fluni- trazepam binding alternated with stripes of reduced autoradiographic labeling (Figs. 8, 9). When the immunoreacted sections or the autoradiograms were compared with adjacent, $\mathrm{CO}$-stained sections (Figs. $7 B, 8 B, 9 B$ ), the stripes showing intense immunoreactivity or high levels of ligand binding were found to correspond to regions that included all of the stripes intensely stained for $\mathrm{CO}$ but these regions also overlapped into the lightly stained $\mathrm{CO}$ stripes. The lightly immunostained stripes and the stripes showing lower levels of ligand binding corresponded to the cen$\operatorname{tral}^{2 / 3}$ of the lightly stained CO stripes. These data demonstrate that receptor immunostaining and ligand binding were at their normal, high levels in normal-eye columns but were reduced in injected/enucleated-eye columns.

The difference in ligand binding was quantified by analyzing sections from normal and enucleated monkeys, which had been processed and exposed simultaneously in the same cassettes (Fig. 9, Table 1). The levels of both ${ }^{3} \mathrm{H}$-muscimol and ${ }^{3} \mathrm{H}$-flunitrazepam binding in layer IVC $\beta$ of normal-eye columns were apparently equal to those found throughout layer IVC $\beta$ of normal monkeys. The binding of both ligands in the adjacent enucleated-eye columns was reduced by $25 \%$ (Table 1 ).

Examination of sections of layer IVC $\beta$ from TTX-injected or enucleated monkeys revealed a reduction in immunostaining of deprived columns even at high magnification. However, even with the higher resolution afforded by the semithin sections, it was not apparent whether the staining was reduced because the 

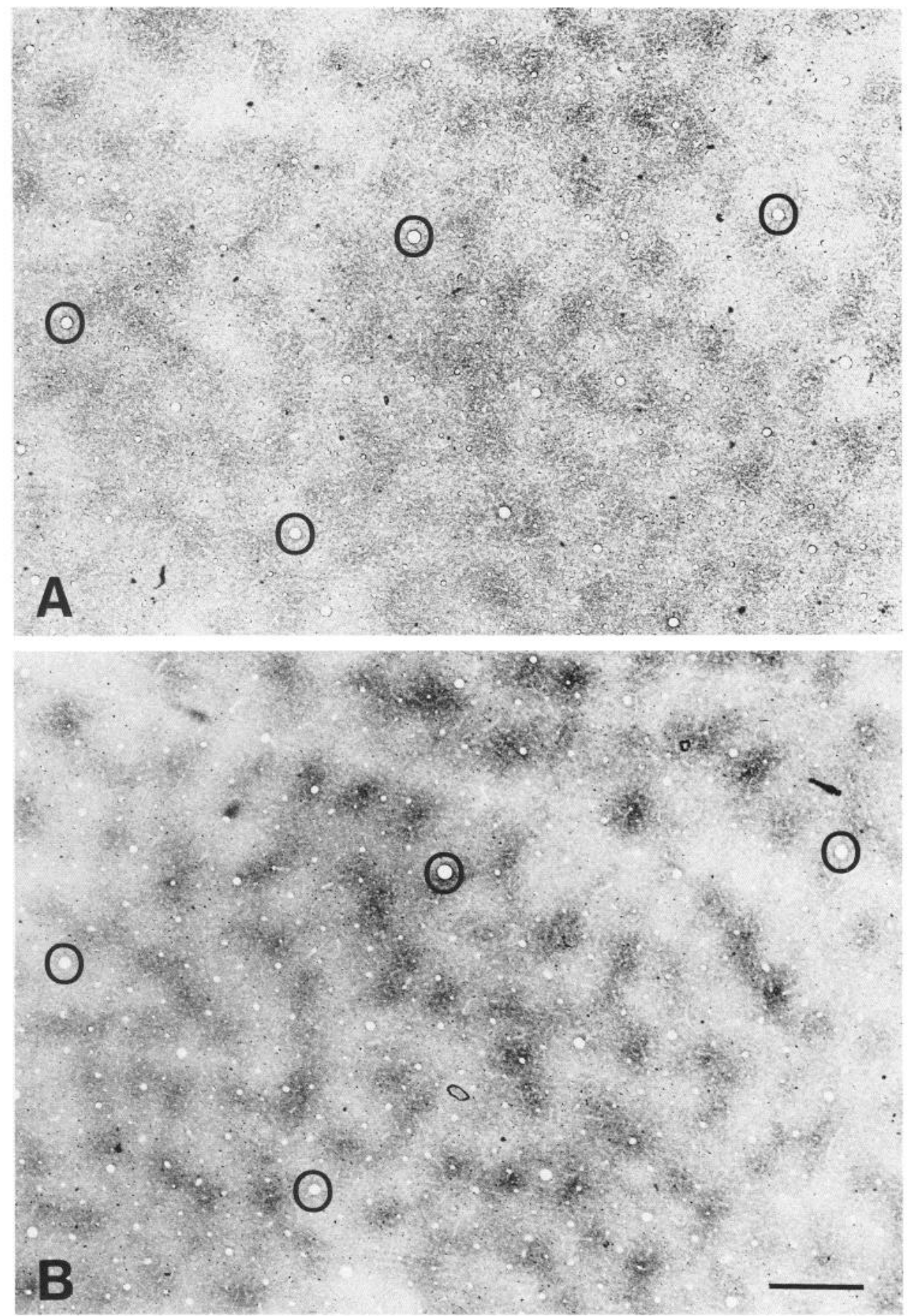

Figure 4. Photomicrographs of tangential sections through layers II and III of area 17. $A$, Immunostaining for $\mathrm{GABA}_{\mathrm{A}}$ receptors is inhomogeneous, with patches of intense staining surrounded by regions of lighter staining. $B, C O$ staining in the section adjacent to $A$ reveals the series of intensely stained patches. By superimposing the profiles of the same, radially oriented blood vessels (circles) in the 2 sections, the positions of the immunostained and $\mathrm{CO}$-stained patches can be compared and are found to coincide. Scale bar, $500 \mu \mathrm{m}$. number of immunoreactive puncta was reduced or because individual puncta were more lightly stained.

Changes in receptor immunostaining were not confined to layer IVC $\beta$ in TTX-injected or enucleated monkeys. In layer IVC $\alpha$, reduced immunostaining was evident in the columns deprived of normal visual input (lightly stained for $\mathrm{CO}$ ) while normal levels of immunostaining were found in normal-eye columns (darkly stained for CO; Fig. 7). In layer IVA, the overall staining of the honeycomb pattern was reduced in deprived-eye columns and remained intense within normal-eye columns. The immunostaining of regions corresponding to the $\mathrm{CO}$ patches in layers II-III, IVB, and VI was also changed and was seen as reductions in immunostaining of deprived-eye patches.

\section{Discussion}

The improved resolution provided by the immunocytochemical method used in this study revealed several novel features of $\mathrm{GABA}_{\mathrm{A}}$ receptor distribution in monkey areas 17 and 18 . In addition, both the immunocytochemical and the ligand-binding results show that even in adult monkeys the receptors in area 17 are subject to rapid changes with manipulations that eliminate or reduce visually driven activity. 

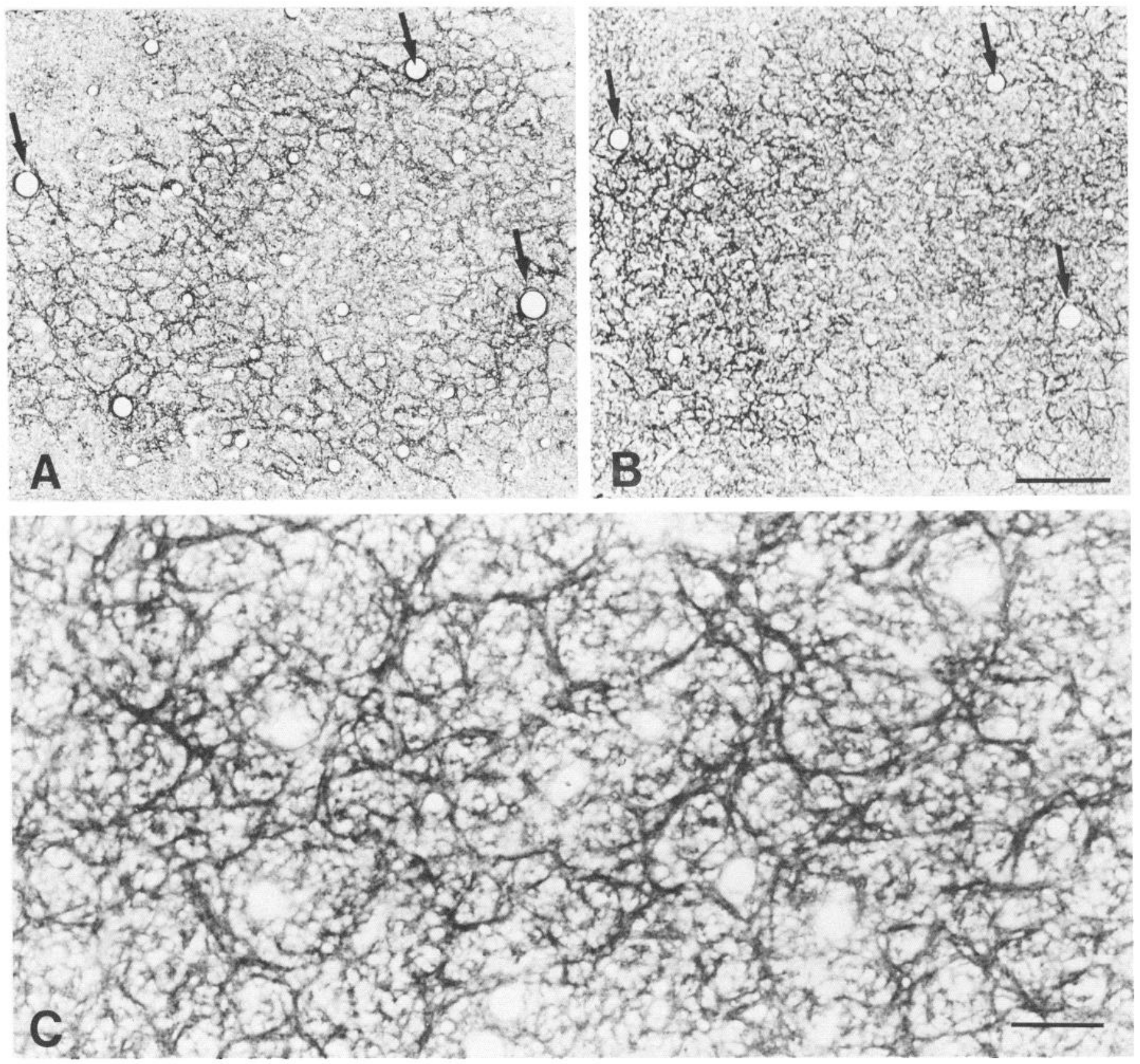

Figure 5. Photomicrographs of tangential sections through layer IVA of area 17. A, Low magnification photomicrograph of a section immunostained for $\mathrm{GABA}_{\mathrm{A}}$ receptors. An irregular plexus, made up of intensely stained walls that surround lightly stained cores, is found in this layer. $B$, Photomicrograph of a CO-stained section $20-\mu \mathrm{m}$ deep to the 1 in $A$. A similar irregular lattice of staining is also seen in this section. By comparing the profiles of the same radially oriented blood vessels (arrows) in the 2 sections, the lattices can be superimposed and many of the intensely stained walls in both sections are found to coincide. $C$, High magnification photomicrograph of GABA receptor immunostaining in layer IVA showing the intensely stained walls and the lightly stained cores. Scale bars, $1 \mathrm{~mm}$ in $A$ and $B, 150 \mu \mathrm{m}$ in $C$.

\section{$G A B A_{A}$ receptor distribution}

The present immunocytochemical and autoradiographic findings demonstrated high densities of $\mathrm{GABA}_{\mathrm{A}}$ receptors in layers II and III, in layer IVC $\beta$, and in layer VI of area 17. This is a similar distribution previously determined with radioligand binding methods (Shaw and Cynader, 1986; Rakic et al., 1988). In agreement with Shaw and Cynader (1986) we found receptor density in layer IVC $\beta$ to be considerably greater than in layer IVC $\alpha$. We also found, however, that immunostained and ra- diolabeled receptors formed a distinctly intense band in layer IVA, a pattern that was not apparent in previous ligand-binding studies. The similarity in the receptor distribution and the distribution of GABA- and GAD-immunoreactive somata and terminals (Hendrickson et al., 1981; Fitzpatrick et al., 1987; Hendry et al., 1987) indicates that the mismatch between neurotransmitter and receptor distribution, which is commonly seen in the CNS (Herkenham and McLean, 1986), is much less evident for the GABA system in monkey area 17. Identical laminar distributions of GABA neurons (Hendry et al., 1987) 

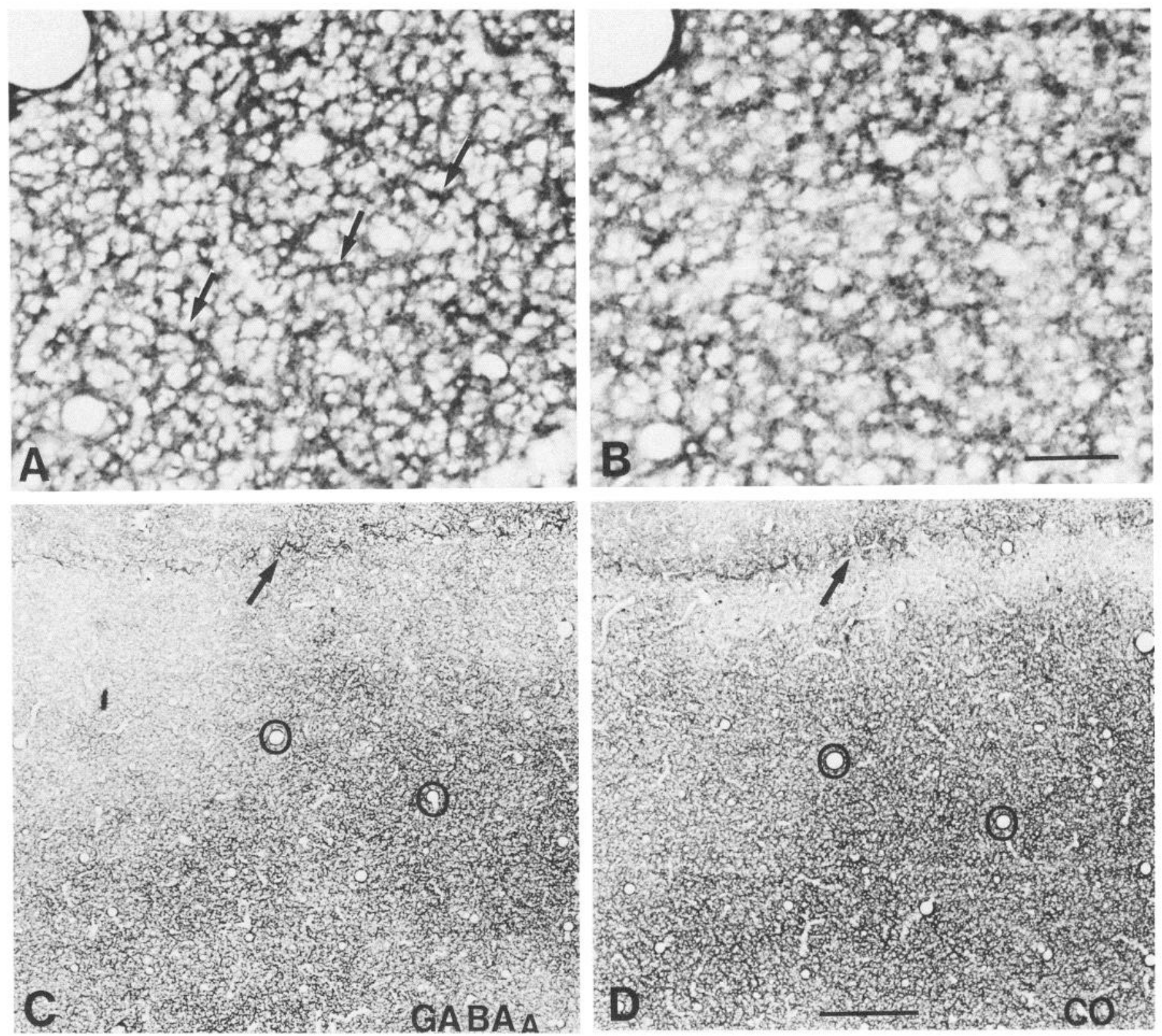

Figure 6. Photomicrographs of $\mathrm{GABA}_{\mathrm{A}}$ receptor immunostaining $(A$ and $C)$ and $\mathrm{CO}$ staining $(B$ and $D)$ in tangential sections through layer IV of area 17. At high magnification $(A)$ the receptor immunostaining in layer IVC $\beta$ is seen as a fine, regular lattice in which short, intensely stained strands (arrows) surround groups of unstained somata. CO staining of the same region $(B)$ is also uneven. At low magnification, both the receptor immunostaining $(C)$ and the CO staining $(D)$ in layer IVC are relatively uniform. Profiles of the same radially oriented blood vessels are circled in the 2 micrographs. Layer IVA in both sections (arrows) is also intensely stained for receptors and for CO. Scale bars, $50 \mu \mathrm{m}$ in $A$ and $B, 300 \mu \mathrm{m}$ in $C$ and $D$.

and $\mathrm{GABA}_{\mathrm{A}}$ receptors in area 18 and in the sensory-motor areas (Huntley et al., in press) also indicate that there is little mismatch in the cerebral cortex as a whole. The very tight correlation between $\mathrm{GABA}$ terminal and $\mathrm{GABA}_{\mathrm{A}}$ receptor distributions does not preclude the possibility that other GABA receptor subtypes may be present in the monkey visual cortex or sensory-motor cortex. However, the correlation indicates that the relative densities of presynaptic terminals and postsynaptic receptors are approximately equal throughout area 17 and the other areas and suggests that no population, restricted to certain layers or to certain compartments, is likely to have transmission mediated only by $\mathrm{GABA}_{\mathrm{B}}$ receptors.
The patches of intense CO staining in layers II and III of area 17 are regions in which neurons differ physiologically and connectionally from the surrounding cells (Horton and Hubel, 1981; Livingstone and Hubel, 1982, 1983, 1984a, b; Tootell et al., 1988a, b; Ts'o and Gilbert, 1988). The patches are also chemically distinct (Hendrickson, 1985). Although GABA somata are no more densely packed in the patches than around them (Fitzpatrick et al., 1987; Hendry et al., 1987), a distinct population of large GABA terminals is restricted to the patches and allows them to be identified in GAD- or GABA-immunostained preparations (Hendrickson et al., 1981; Fitzpatrick et al., 1987; Hendry et al., 1987). In addition, subpopulations of GABA 


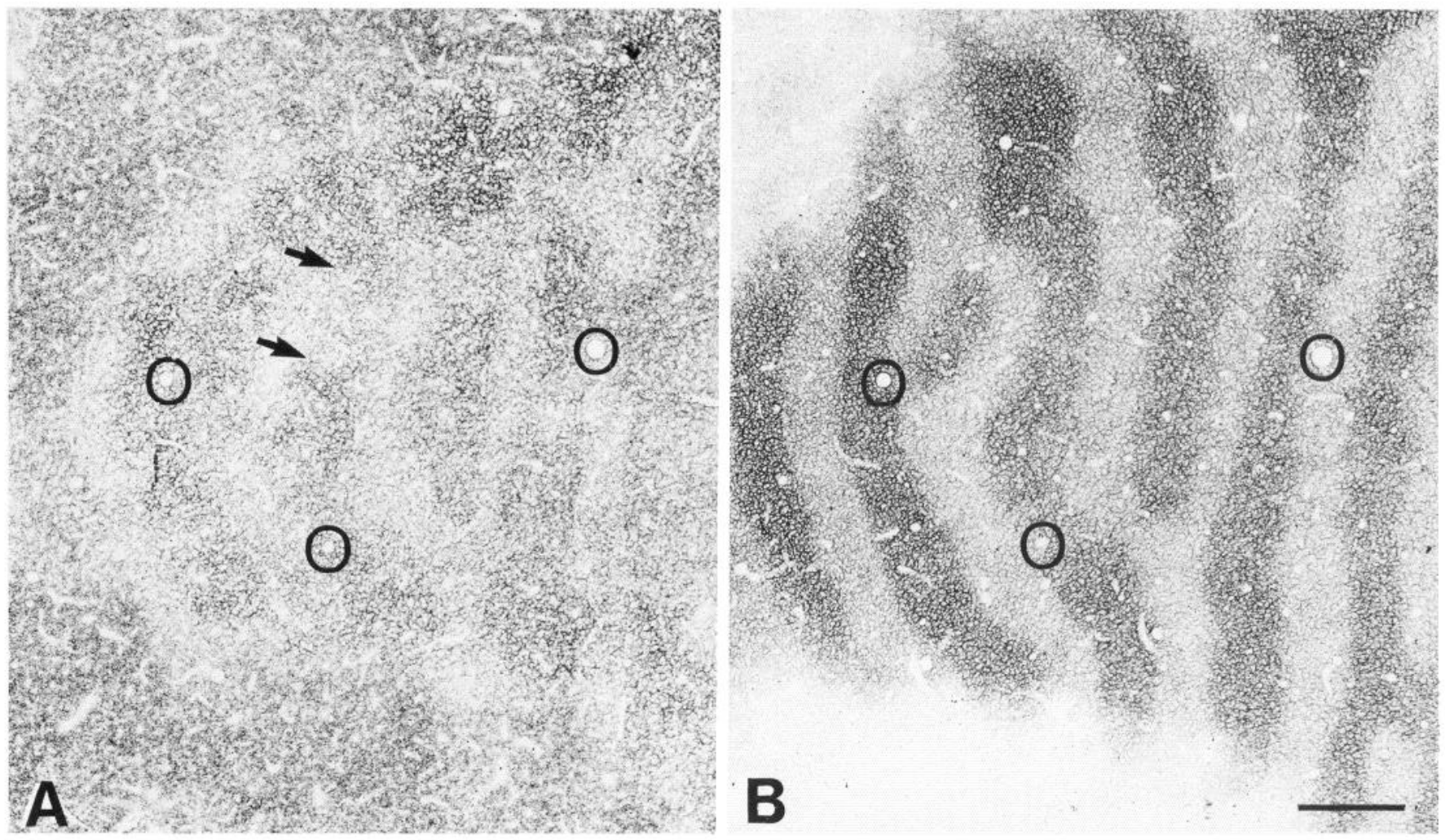

Figure 7. Photomicrographs of tangential sections through layer IVC of a monkey injected intravitreally with TTX $5 \mathrm{~d}$ prior to death. $A$, GABA receptor immunostaining in layer IVC consists of stripes of intense immunostaining that alternate with stripes of lighter immunostaining. Individual stripes pass through both layer IVC $\beta$ and the more lightly stained layer IVC $\alpha$ (between arrows). $B$, Section adjacent to $A$ stained for CO. Intense staining of normal-eye dominance stripes and light staining for injected-eye stripes are evident. Comparison of the profiles of radially oriented blood vessels (circles) shows that the receptor immunostaining in the injected-eye columns is reduced relative to that in the normal-eye columns. Scale bar, $500 \mu \mathrm{m}$.

neurons in the patches are distinguished by the presence of specific surface antigens and of certain neuropeptides (Hendry et al., 1988a, b).

The findings of the present study indicate that immunostained puncta, which most likely correspond to aggregates of $\mathrm{GABA}_{\mathrm{A}}$ receptors, are either more numerous or more immunoreactive (possibly because they are larger) in the patches than around them. The difficulty we and others (Rakic et al., 1988) have had in demonstrating increased ligand binding in the patches is probably caused by the lower resolution of this method in comparison with that obtained with immunocytochemistry. An increased number of receptor aggregates in the patches might indicate that the large GABA terminals there give rise to a greater number of synaptic contacts with a correspondingly larger number of receptors. However, electron microscopic observations indicate that the percentage of symmetric contacts, presumably formed by GABA terminals, is the same within the patches as outside them (Carroll and Wong-Riley, 1984). A second possibility, that of increased immunoreactivity of individual receptors, would suggest that GABA terminals in the patches are apposed synaptically to larger receptor aggregates or to aggregates containing a greater concentration of receptor protein.

The intense $\mathrm{GABA}_{\mathrm{A}}$ immunostaining in layer IVA of area 17 forms a honeycomb pattern identical to the pattern of $\mathrm{CO}$ staining (Livingstone and Hubel, 1982; Humphrey and Hendrickson, 1983; Horton, 1984) and to the distribution of geniculocortical axon terminals (Hendrickson et al., 1978; Livingstone and $\mathrm{Hu}-$ bel, 1982; Blasdel and Lund, 1983; Itaya et al., 1984). The walls of the honeycomb not only display intense immunostaining for $\mathrm{GABA}_{\mathrm{A}}$ receptors but also contain a very high density of GADpositive terminals (Fitzpatrick et al., 1987). Thus the presence

Table 1. Specific binding of ${ }^{3} \mathrm{H}$-muscimol and ${ }^{3} \mathrm{H}$-flunitrazepam in layer IVC $\beta$ of normal monkeys and in deprived columns and nondeprived columns of monocularly enucleated monkeys.

Ligand Binding ( $\mathrm{fmol} / \mathrm{mg}$ of tissue) in layer IVC $\beta$

Muscimol

Normal $59.8(+4.3)$

Enucleated 1

Deprived

$49(+3.5)^{*}$

Nondeprived

$63.0(+5.6)$

Enucleated 2

Deprived

$44.1(+4.4)^{*}$

Nondeprived

$57.5(+4.1)$

Flunitrazepam

Normal

$183.7(+17.8)$

Enucleated 1

Deprived

Nondeprived

$141.6(+22.1)^{*}$

Enucleated 2

Deprived

$194.2(23.7)$

Nondeprived

$148.9(+27.9)^{*}$

$188.6(26.2)$

No significant difference in binding exists between layer IVC $\beta$ of a normal monkey and layer IVC $\beta$ of a nondeprived eye column. However, the binding in layer IVC $\beta$ of a deprived-eye column is significantly reduced. ${ }^{*} p<0.001$. 

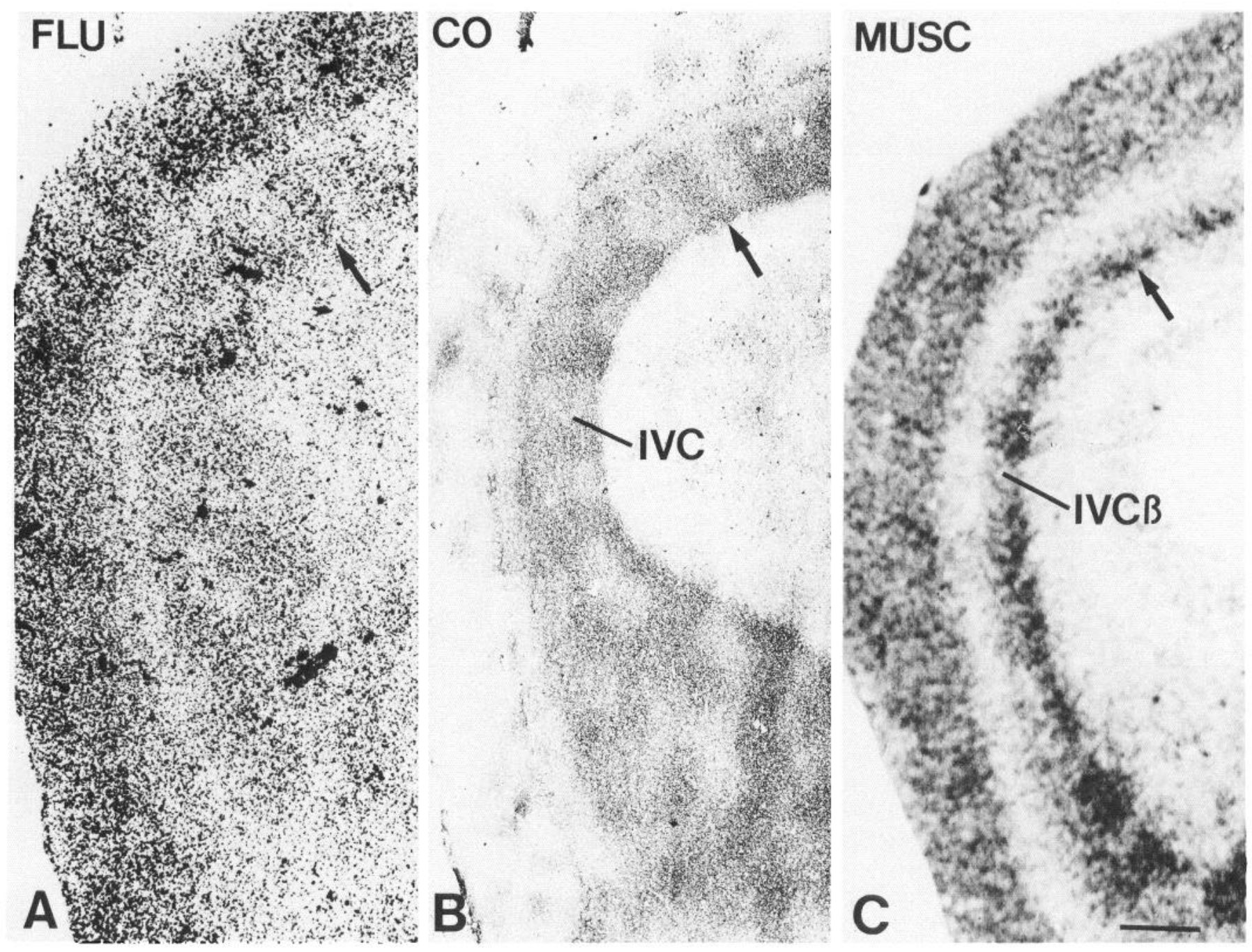

Figure 8. Ligand binding in area 17 of an enucleated monkey. $A$, Autoradiogram of ${ }^{3} \mathrm{H}$-flunitrazepam ( FLU) binding in a tangential section, showing high levels in layers I-III and IVC. The binding in layer IVC is not uniform but is made up of stripes of high binding that alternate with stripes of lower binding. $B$, CO staining of the same section as $A$, demonstrating the alternating darkly stained (normal-eye) and lightly stained (enucleated-eye) stripes in layer IVC. $C$, Digitized image of section adjacent to $A$ and $B$ in which ${ }^{3} \mathrm{H}$-muscimol (MUSC) was bound. Dense binding is found in layer IVC $\beta$, where alternating rows of higher and lower binding are found. Comparison of the CO-stained section with the autoradiograms reveals higher binding in normal-eye stripes (arrows) than in enucleated-eye stripes. Scale bars, $500 \mu \mathrm{m}$.

of intense $\mathrm{GABA}_{\mathrm{A}}$ immunostaining in this layer IVA pattern, as well as in layers IVC and VI, in which geniculocortical axons also terminate and where high densities of GABA somata and terminals are also found, further demonstrates the close correlation between $\mathrm{GABA}$ terminals and $\mathrm{GABA}_{\mathrm{A}}$ receptors and the spatial correlation between the GABA system and geniculocortical terminations in area 17. That the somata of GABA neurons tend to be most densely packed in thalamocortical recipient layers has been noted for several areas of monkey cerebral cortex (Hendrickson et al., 1981; Hendry et al., 1987; Schwartz et al., 1988). From the present examination and that of Huntley et al. (in press), it would appear that $\mathrm{GABA}_{\mathrm{A}}$ receptors are also densest within these layers. Only 1 major exception to the correlation of thalamic inputs and the GABA system was noted: in area 18, where thalamocortical axons from the pulvinar terminate in bands (Curcio and Harting, 1978) that are also stained for CO (Livingstone and Hubel, 1983), $\mathrm{GABA}_{\mathrm{A}}$ receptors are more widely dispersed.

$\mathrm{GABA}_{\mathrm{A}}$ receptor immunostaining splits layer IV of area 18 into a superficial lightly stained band and a deep, intensely stained band. The same subdivision of layer IV was seen previously with ${ }^{3} \mathrm{H}$-flunitrazepam binding (Rakic et al., 1988). These data suggest that the morphologically homogeneous layer IV of area 18 is made up of chemically distinct subdivisions.

\section{$G A B A_{A}$ receptor plasticity}

Elimination of activity in 1 retina of an adult monkey produces a rapid reduction in the number of neurons immunoreactive for GAD and GABA in deprived-eye columns of area 17 (Hendry and Jones, 1986, 1988). Because the total population of neurons remains intact within area 17 and the normal pattern of GABA immunostaining can be restored following a return to binocular vision, we interpreted the loss of immunoreactivity to result from an activity-dependent reduction in enzyme and neurotransmitter levels (Hendry and Jones, 1986, 1988). These findings have implications for the present study in which the data are compatible with 2 possibilities: (1) the number of $\mathrm{GABA}_{\mathrm{A}}$ receptors on neurons in deprived-eye columns is reduced by 
loss of activity and by the accompanying reduction in presynaptic GABA levels; and (2) receptors in deprived-eye columns undergo a change in conformation that simultaneously alters their immunoreactivity and their ability to bind muscimol and benzodiazepines. These 2 possibilities, a reduction in receptor number or a reduction in receptor affinity, can be distinguished by further ligand-binding experiments, which are in progress.

Either of the 2 possible changes in $\mathrm{GABA}_{\mathrm{A}}$ receptors would likely reduce the effectiveness of GABA transmission in deprived-eye columns. In other parts of the CNS and in peripheral tissues, denervation or loss of afferent activity often leads to increased receptor number in the postsynaptic target (Lømo and Rosenthal, 1972; Frank et al., 1975; Creese et al., 1977; Biggio et al., 1981; Drew et al., 1987), and to supersensitivity to particular neurotransmitters (Trendelenburg, 1966; Ungerstedt, 1971; Schwartz et al., 1978). This is especially true for receptors to the neurotransmitter used by the removed or silenced afferent axons. The present observations indicate that a different response occurs for receptors to the neurotransmitter employed by a large population of interneurons in monkey area 17 . However, since the density of $\mathrm{GABA}_{\mathrm{A}}$ receptors increases following the loss of afferent input to several regions of the CNS, including area 17 of monocularly deprived kittens (Skangiel-Kramska and Kossut, 1984; Shaw and Cynader, 1988; see, however, Mower et al., 1986), the effect seen in the monkey visual cortex cannot be generalized to all $\mathrm{GABA}_{\mathrm{A}}$ receptors or even to $\mathrm{GABA}_{\mathrm{A}}$ receptors throughout the cerebral cortex. Instead, the effect would appear to be a specific response to conditions found in area 17 of adult monkeys.

As was found previously for GABA and GAD immunostaining (Hendry and Jones, 1986, 1988), changes in receptor immunostaining with monocular deprivation do not occur perfectly at the border between the 2 sets of eye dominance columns in layer IVC. Instead the greatest change both for GABA and receptor immunostaining takes place in the central two-thirds of the deprived-eye columns. These data suggest that the most profound changes in GABA transmission may occur at the centers of the deprived columns.

GABA is very likely the major inhibitory neurotransmitter in the mammalian cerebral cortex (Krnjević, 1984) and most of the direct inhibitory actions are thought to be mediated through the bicuculline-sensitive GABA $_{A}$ receptor (Sillito, 1984). Thus, parallel reductions in $\mathrm{GABA}$ and $\mathrm{GABA}_{\mathrm{A}}$ receptors suggest that neuronal inhibition would be reduced within deprived-eye columns of adult monkeys. Such a mechanism may contribute to the functional expansion of ocular dominance columns (Hubel et al., 1977; LeVay et al., 1980) and the psychophysical changes in central visual processing (Harweth et al., 1983, 1986) in adult monkeys following the removal of one eye, as well as to the functional plasticity that occurs in the first somatic sensory area of the adult monkey following surgical manipulations of the periphery (Merzenich et al., 1983; Kaas et al., 1983).

The present study is the first indication that neurotransmitter receptors remain plastic within the adult monkey visual cortex, although changes in the distribution of neurotransmitter receptors have been well documented for area 17 of normal and visually deprived kittens (Shaw et al., 1984; Aoki et al., 1986). Certain types of receptors in cat area 17 have been localized to postsynaptic sites (van Huizen et al., 1988) while indirect evidence suggests that at least 1 , the nicotinic receptor, is localized presynaptically on geniculocortical axon terminals (Prusky et al., 1987; Parkinson et al., 1988). The changes we observed in
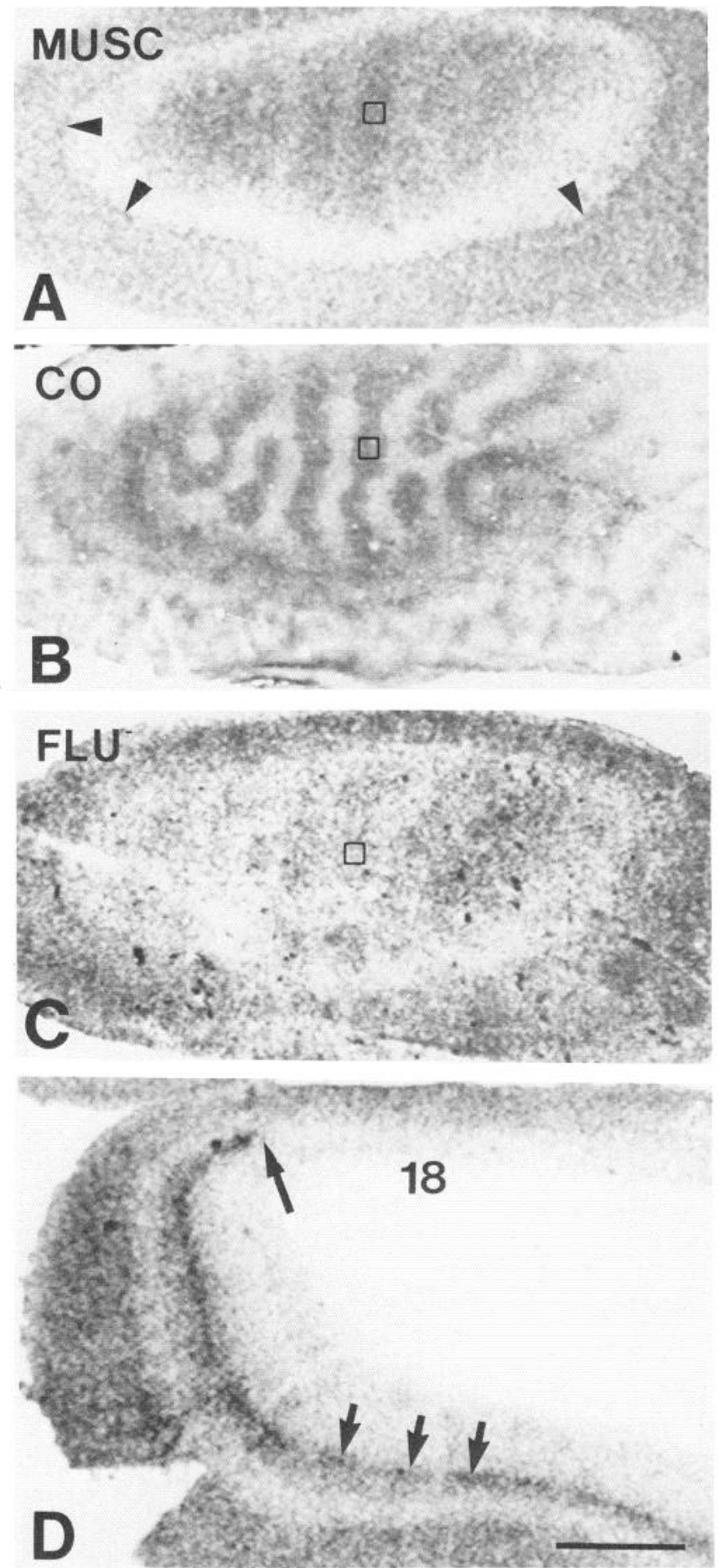

Figure 9. Digitized images of autoradiograms and CO-stained tangential sections through areas 17 and 18 of an enucleated monkey. $A-C$, Images of sections in which quantitative analyses were performed. Autoradiograms of ${ }^{3} \mathrm{H}$-muscimol (MUSC) and ${ }^{3} \mathrm{H}$-flunitrazepam (FLU) binding and the same sections after $\mathrm{CO}$ staining were superimposed using an image analysis system. Normal-eye and enucleated-eye stripes were identified in the $\mathrm{CO}$ sections and counts were made of regions in the autoradiograms enclosed by the boxes. Similar counts were made from autoradiograms of 2 normal monkeys. $A$ shows that, in addition to the changes in muscimol binding within layer IVC, binding in layer IVA (arrowheads) is greater than that of neighboring layers. $D,{ }^{3} \mathrm{H}-$ muscimol binding in a tangential section that includes both areas 17 and 18. Differences in the density and pattern of binding marks the border (large arrow) between the 2 areas. Higher binding within normal-eye columns (small arrows) of area 17 is also evident. 
the distribution of $\mathrm{GABA}_{\mathrm{A}}$ receptors may have occurred only at postsynaptic sites or could have involved partly or entirely presynaptic sites, possibly also on geniculocortical axons. Evidence for either site is currently lacking and will require electron microscopic examination. Such precise localization of the receptor is important to determine which class or classes of neurons in the adult monkey visual system are directly or indirectly affected by visual deprivation.

\section{Conclusions}

The relative levels of immunostaining for $\mathrm{GABA}_{\mathrm{A}}$ receptors in the monkey visual cortex indicate that the density of these receptors varies not only across layers but also within certain layers of normal animals. The close correlation between the intensity of receptor immunostaining and the density of $\mathrm{G} \Lambda \mathrm{B} \Lambda$ terminals suggests that the synapses formed by most, if not all populations of GABA neurons in areas 17 and 18 are associated with $\mathrm{GABA}_{\mathrm{A}}$ receptors, as in the sensory-motor areas (Huntley et al., 1989). The presence of the greatest density of receptors in the layers and sublaminar compartments receiving geniculocortical contacts is a further indication of the close correlation between the innervation by the excitatory thalamic afferents and the inhibitory GABA neurons. Finally, the changes in receptor immunostaining and ligand binding following the loss of retinal activity suggest that the density of $\mathrm{GABA}_{\mathrm{A}}$ receptors in area 17 is directly related to levels of neural activity.

\section{References}

Aoki C, Kaufman D, Rainbow TC (1986) The ontogeny of the laminar distribution of $\beta$-adrenergic receptors in the visual cortex of cats, normally reared and dark-reared. Dev Brain Res 27:109-116.

Biggio G, Corda MG, Concas A, Gessa GL (1981) Denervation supersensitivity for benzodiazepine receptors in the rat substantia nigra. Brain Res 220:344-349.

Blasdel GG, Lund JS (1983) Terminations of afferent axons in macaque striate cortex. J Neurosci 3:1389-1413.

Bowery NG (1983) Classification of GABA receptors. In: The GABA receptors (Enna SJ, ed), pp 177-213. Clifton, NJ: Humana.

Bowery NG, Price GW, Hudson AL, Hill DR, Wilkin GP, Turnbull ML (1984) GABA receptor multiplicity: visualization of different receptor types in the mammalian CNS. Neuropharmacol 23:219-231.

Carroll EW, Wong-Riley MTT (1984) Quantitative light and electron microscopic analysis of cytochrome oxidase-rich zones in the striate cortex of the squirrel monkey. J Comp Neurol 222:1-17.

Creese I, Burt DR, Snyder S (1977) , Dopamine receptor binding enhancement accompanies lesion-induced behavioral supersensitivity. Science 197:596-598.

Curcio CA, Harting JK (1978) Organization of pulvinar afferents to area 18 in the squirrel monkey: evidence for stripes. Brain Res 143: $155-161$.

deBlas AL, Vitorica J, Friedrich P (1988) Localization of the GABA receptor in the rat brain with a monoclonal antibody to the 57,000 Mr peptide of the $\mathrm{GABA}_{\mathrm{A}}$ receptor/benzodiazepine receptor $/ \mathrm{Cl}^{-}$ channel complex. J Neurosci 8:602-614.

Drew JP, Westrum LE, Baskin DB, Franck JE (1987) Benzodiazepine binding increases in the superficial laminae of the trigeminal subnucleus caudalis following central rhizotomy. Neurosci Lett 80:3943.

Fitzpatrick D, Lund JS, Schmechel DE, Towles AC (1987) Distribution of GABAergic neurons and axon terminals in the macaque striate cortex. J Comp Neurol 264:73-91.

Frank E, Gautvik K, Sommerschild H (1975) Cholinergic receptors at denervated mammalian motor end-plates. Acta Physiol Scand 95: $66-76$.

Harweth RS, Smith EL III, Crawford MLJ, von Noorden GK (1983) Effects of enucleation of the nondeprived eye on stimulus deprivation amblyopia in monkeys. Invest Ophthalmol Vis Sci 25:10-17.

Harweth RS, Smith EL III, Duncan GC, Crawford MLJ, von Noorden
GK (1986) Effects of enucleation of the fixating eye on strabismic amblyopia in monkeys. Invest Ophthalmol Vis Sci 27:246-254.

Hendrickson AE (1985) Dots, stripes and columns in monkey visual cortex. Trends Neurosci 8:406-410.

Hendrickson AE, Wilson JR, Ogren MP (1978) The neuroanatomical organization of pathways between the dorsal lateral geniculate nucleus and visual cortex in Old World and New World primates. J Comp Neurol 182:123-136.

Hendrickson AE, Hunt SP, Wu JY (1981) Immunocytochemical localization of glutamic acid decarboxylase in monkey striate cortex. Nature 292:605-607.

Hendry SHC, Jones EG (1986) Reduction in number of GABA immunostained neurons in deprived-eye dominance columns of monkey area 17. Nature 320:750-753.

Hendry SHC, Jones EG (1988) Activity-dependent regulation of GABA expression in the visual cortex of adult monkeys. Neuron 1:701-712.

Hendry SHC, Jones EG, Emson PC (1984) Morphology, distribution and synaptic relations of somatostatin and neuropeptide $Y$ immunoreactive neurons in rat and monkey neocortex. J Neurosci 5:22542268 .

IIendry SIIC, Schwark IID, Jones EG, Yan J (1987) Numbers and proportions of GABA immunoreactive neurons in different areas of monkey cerebral cortex. J Neurosci 7:1503-1520.

Hendry SHC, Jones EG, Hockfield S, McKay RDG (1988a) Neuronal populations stained with the monoclonal antibody Cat-301 in the mammalian cerebral cortex and thalamus. J Neurosci 8:518-542.

Hendry SHC, Jones EG, Burstein N (1988b) Activity-dependent regulation of tachykinin-like immunoreactivity in neurons of the monkey primary visual cortex. J Neurosci 8:1225-1238.

Herkenham M, McLean S (1986) Mismatches between receptor and transmitter localizations in the brain. In: Quantitative receptor autoradiography (Boast CA, Snowhill EW, Altar CA, eds), pp 137-171. New York: Liss.

Horton JC (1984) Cytochrome oxidase patches: a new cytoarchitectonic feature of monkey visual cortex. Phil Trans R Soc (Lond) 304: 199-253.

Horton JC, Hubel DH (1981) Regular patchy distribution of cytochrome oxidase staining in primary visual cortex of macaque monkey. Nature 292:762-764.

Houser CR, Olsen RW, Richards JG, Möhler H (1988) Immunohistochemical localization of benzodiazepine/GABA $\mathrm{A}_{\mathrm{A}}$ receptors in the human hippocampal formation. J Neurosci 8:1370-1383.

Hsu SM, Raine L, Fanger H (1981) Use of avidin-biotin-peroxidase complex $(\mathrm{ABC})$ in immunoperoxidase techniques: a comparison between $\mathrm{ABC}$ and unlabeled antibody (PAP) procedures. J Histochem Cytochem 29:577-580.

Hubel DH, Wiesel TN, LeVay S (1977) Plasticity of ocular dominance columns in monkey striate cortex. Phil Trans R Soc (Lond) 278:131163.

Humphrey AL, Hendrickson AE (1983) Background and stimulusinduced patterns of high metabolic activity in the visual cortex (area 17) of the squirrel and macaque monkey. J Neurosci 3:345-358.

Huntley GW, Jones EG, deBlas AL (1990) GABA A $_{A}$ receptor immunoreactivity in adult and developing monkey sensory-motor cortex. Exp Brain Res (in press).

Itaya SK, Itaya PW, Van Hoesen GW (1984) Intracortical termination of the retino-geniculo-striate pathway studied with transynaptic tracer (wheat germ agglutinin-horseradish peroxidase) and cytochrome oxidase staining in the macaque monkey. Brain Res 304:303-310.

Johnston GAR, Allan RD, Skerritt JH (1984) GABA receptors. In: Handbook of neurochemistry, Vol 6 (Lathja A, ed), pp 213-237. New York: Plenum.

Kaas JH, Merzenich MM, Killackey HP (1983) The reorganization of somatosensory cortex following peripheral nerve damage in adult and developing mammals. Annu Rev Neurosci 6:325-356.

Krnjević K (1984) Neurotransmitters in cerebral cortex: a general account. In: Cerebral cortex, Vol 2, functional properties of cortical cells (Jones EG, Peters A, eds), pp 39-61. New York: Plenum.

Kuljis RO, Rakic P (1989) Distribution of neuropeptide Y-containing perikarya and axons in various neocortical areas in the macaque monkey. J Comp Neurol 280:383-392.

Kuriyama K, Taguchi J (1987) Purification of $\gamma$-aminobutyric acid receptor, benzodiazepine receptor and $\mathrm{Cl}^{-}$channel from bovine cerebral cortex by benzodiazcpinc affinity gel column chromatography. Neurochem Int 10:253-263. 
LeVay S, Wiesel TN, Hubel DH (1980) The development of ocular dominance columns in normal and visually deprived monkeys. $J$ Comp Neurol 191:1-51.

Livingstone MS, Hubel DH (1982) Thalamic inputs to cytochrome oxidase-rich regions to monkey visual cortex. Proc Natl Acad Sci USA 79:6098-6101.

Livingstone MS, Hubel DH (1983) Specificity of cortico-cortical connections in monkey visual system. Nature 304:531-534.

Livingstone MS, Hubel DH (1984a) Anatomy and physiology of a color system in the primate visual cortex. J Neurosci 4:309-356.

Livingstone MS, Hubel DH (1984b) Specificity of intrinsic connections in primate primary visual cortex. J Neurosci 4:2830-2835.

Lømo T, Rosenthal J (1972) Control of ACh sensitivity by muscle activity in the rat. J Physiol (Lond) 221:493-513.

Merzenich MM, Kaas JH, Wall JT, Sur M, Nelson RJ, Felleman DJ (1983) Progression of change following median nerve section in the cortical representation of the hand in areas $3 \mathrm{~b}$ and 1 in adult owl and squirrel monkeys. J Neurosci 10:639-665.

Mower GD, White WF, Rustad R (1986) [ $\left.{ }^{3} \mathrm{H}\right]$ Muscimol binding of GABA receptors in the visual cortex of normal and monocularly deprived cats. Brain Res 308:253-260.

Olsen RW (1981) GABA-benzodiazepine-barbiturate receptor interactions. J Neurochem 37:1-13.

Olsen RW (1982) Drug interactions at the GABA receptor ionophore complex. Ann Rev Pharmacol Toxicol 22:245-277.

Parkinson D, Kratz KE, Daw NW (1988) Evidence for a nicotinic component to the actions of acetylcholine in cat visual cortex. Exp Brain Res 73:553-568.

Prusky GT, Shaw C, Cynader MS (1987) Nicotine receptors are located on lateral geniculate terminals in cat visual cortex. Brain Res 412: 131-138.

Rakic P, Goldman-Rakic PS, Gallagher D (1988) Quantitative autoradiography of major neurotransmitter receptors in the monkey striate and extrastriate cortex. J Neurosci 8:3670-3690.

Richards JG, Möhler H, Schoch P, Haring P, Takacs B, Stahli Ch (1984) The visualization of neuronal benzodiazepine receptors in the brain by autoradiography and immunohistochemistry. J Receptor Res 4 : $657-669$.

Richards JG, Schoch P, Haring P, Takacs B, Möhler H (1987) Resolving $\mathrm{GABA}_{\mathrm{A}}$ /benzodiazepine rcceptors: ccllular and subccllular localization in the CNS with monoclonal antibodies. J Neurosci 7: $1866-1886$

Roberts E (1986) GABA: the road to neurotransmitter status. In: Benzodiazepine/GABA receptors and chloride channels: structural and functional properties (Olsen RW, Venter JC, eds), pp 1-39. New York: Liss.

Schoch P, Richards JG, Haring P, Takacs B, Stahli C, Staelin T, Haefely W, Möhler H (1985) Co-localization of GABA receptors and benzodiazepine receptors in the brain shown by monoclonal antibodies. Nature 314:168-171.

Schwartz JC, Constentin J, Martres MP, Protais P, Baudry M (1978) Modulation of receptor mechanisms in the CNS: hyper- and hyposensitivity to catecholamines. Neuropharmacol 17:665-685.
Schwartz ML, Zheng D-S, Goldman-Rakic PS (1988) Periodicity of GABA-containing cells in primate prefrontal cortex. J Neurosci 8: 1962-1970.

Shaw C, Cynader M (1986) Laminar distribution of receptors in monkey (Macaca fascicularis) geniculostriate system. J Comp Neurol 248: 301-312.

Shaw C, Cynader M (1988) Unilateral eyelid suture increases GABA receptors in cat visual cortex. Dev Brain Res 40:148-153.

Shaw C, Needler MC., Cynader M (1984) Ontogenesis of muscimol binding sites in cat visual cortex. Brain Res Bull 13:331-334.

Sillito AM (1984) Functional considerations of the operation of GABAergic inhibitory processes in the visual cortex. In: Cercbral cortex, Vol 2, functional properties of cortical cells (Jones EG, Peters A, eds), pp 91-117. New York: Plenum.

Skangiel-Kramska J, Kossut M (1984) Increase of GABA receptor binding activity after short lasting monocular deprivation in kittens. Acta Neurobiol Exp 44:33-39.

Tallman J, Gallagher D (1985) The GABAergic system: a locus of benzodiazepine action. Ann Rev Neurosci 8:21-44.

Tootell RBH, Silverman MS, Hamilton SL, DeValois RL, Switkes E (1988a) Functional anatomy of macaque striate cortex. III. Color. J Neurosci 8:1569-1593.

Tootell RBH, Silverman MS, Hamilton SL, Switkes E, DeValois RL (1988b) Functional anatomy of macaque striate cortex. V. Spatial frequency. J Neurosci 8:1610-1624.

Trendelenburg U (1966) Mechanisms of supersensitivity and subsensitivity to sympathomimetic amines. Pharmacol Rev 18:629-640.

Ts'o DY, Gilbert CD (1988) The organization of chromatic and spatial interactions in the primate striate cortex. J Neurosci 8:1712-1727.

Ungerstedt U (1971) Postsynaptic supersensitivity after 6-hydroxydopamine induced degeneration of the nigro-striatal system. Acta Scand Physiol 82:69-93.

Unnerstall JR, Niehoff DL, Kuhar MJ, Palacios JM (1982) Quantitative receptor autoradiography using $\left[{ }^{3} \mathrm{H}\right] \mathrm{U}$ ltrofilm: application to multiple benzodiazepine receptors. J Neurosci Methods 6:59-67.

van Huizen F, Strosberg AD, Cynader MS (1988) Cellular and subcellular localisation of muscarinic acetylcholine receptors during postnatal development of cat visual cortex using immunocytochemical procedures. Dev Brain Res 44:296-301.

Vitorica J, Park D, Chin G, deBlas AL (1988) Monoclonal antibodies and conventional antisera to the GABA receptor/benzodiazepine receptor/ $\mathrm{Cl}^{-}$channel complex. J Neurosci 8:615-622.

Wong-Riley MTT (1979) Changes in the visual system of monocularly sutured or enucleated cats demonstrable with cytochrome oxidase histochemistry. Brain Res 171:11-28.

Young WS III, Kuhar MJ (1979) Autoradiographic localization of benzodiazepine receptors in the brains of humans and animals. Nature 280:393-395.

Young WS III, Kuhar MJ (1980) Radiohistochemical localization of benzodiazepine receptors in rat brain. J Pharmacol Exp Ther 212: 337-346. 